1993

\title{
Some Recent Important Trends in Canadian Private International Law
}

Jean-Gabriel Castel

Osgoode Hall Law School of York University, castel@fake.osgoode.yorku.ca

Follow this and additional works at: http://digitalcommons.osgoode.yorku.ca/scholarly_works

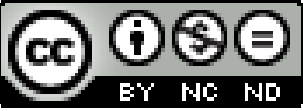

This work is licensed under a Creative Commons Attribution-Noncommercial-No Derivative Works 4.0 License.

\section{Recommended Citation}

Castel, Jean-Gabriel. "Some Recent Important Trends in Canadian Private International Law." Netherlands International Law Review 40.1 (1993): 15-30.

This Article is brought to you for free and open access by the Faculty Scholarship at Osgoode Digital Commons. It has been accepted for inclusion in Articles \& Book Chapters by an authorized administrator of Osgoode Digital Commons. 


\section{SOME RECENT IMPORTANT TRENDS IN CANADIAN PRIVATE INTERNATIONAL LAW}

by J.-G. Castel, Q.C.*

\section{INTRODUCTION}

In 1967, on the occasion of the hundredth anniversary of the Confederation, the author of this paper suggested that it was about time for Canada to join the Hague Conference on Private International Law. Such a move would show to everyone that Canada's legal horizons and objectives had become world wide. ${ }^{1}$ The government of the day followed this suggestion and, in 1968, Canada joined the Conference. Since that time, Canada has participated actively in its work as well as that of other international organizations devoted to the unification of law especially in the area of commercial law. ${ }^{2}$ It is, therefore, appropriate to examine recent trends in the field of private international law in Canada on the occasion of the hundredth anniversary of the Hague Conference and to ascertain the extent to which Canadian rules have been influenced by its conventions.

Due to the limited space available, this paper will examine only the most important aspects of these new trends, namely the adoption of conventions and model laws prepared by the Hague Conference, and other international bodies and the jurisprudential move towards the principle of proximity. Mention will also be made of the private international rules in the new Civil Code of Quebec.

2.

\section{CONVENTIONS AND MODEL LAWS}

Before ascertaining the direct influence of the Hague Conference or other international organizations on the development of private international law rules

* Distinguished Research Professor at Osgoode Hall Law School, York University, Toronto, where he teaches private international law and international business law and economic relations.

1. J.-G Castel, 'Canada and the Hague Conference on Private International Law: 1983-1967', 47 Can. Bar Rev. (1967) p. 1.

2. In 1968 Canada joined the International Institute for the Unification of Private Law. It has also participated in the work of the United Nations Commission on International Trade and of the International Civil Aviation Organization. 
in Canada, it should be mentioned that Canada is a federal State whose constitution $^{3}$ divides the legislative power between the federal parliament and the provincial legislatures. Some private international law rules fall wholly or partly within the legislative competence of the provinces, while others come within the exclusive jurisdiction of the federal parliament. Implementation of treaties must be done by the competent legislative body. With respect to the negotiation and conclusion of treaties, the Federal Government has taken the position that it represents all of Canada. However, it will co-operate with the provinces in fields within their legislative competence. Thus, although Canada is a member of the Hague Conference, its delegation often comprises persons appointed in consultation with the provinces.

To avoid the constitutional and international difficulties that might arise if provincial legislation required for the fulfilment of an international obligation were not passed, prior consultations usually take place and agreement is reached with the provinces before Canada signs and ratifies a treaty. Actually, unless it contains a federal State clause Canada will not sign a treaty until it has received the unanimous support of all the provinces. These difficulties are minimized when the treaty merely contains a model law to be recommended for adoption by the provinces.

\section{$2.1 \quad$ Hague Conventions}

Canada has not been too keen to accede to international conventions adopted before it joined the Conference that did not contain a federal State clause. However, on September 26, 1988, Canada acceded to the Convention on the Service Abroad of Judicial and Extrajudicial Documents in Civil and Commercial Matters concluded on November 15, 1965. This was done after all provincial and federal rules of court had been amended accordingly. ${ }^{4} \mathrm{~A}$ declaration was made against certain forms of service, and regarding translation requirements and delays.

The October 5th, 1961 Convention Abolishing the Requirement of Legalisation for Foreign Public Documents is still being considered. Canada will accede to it if it receives positive replies from all the provinces.

The Convention on the Taking of Evidence Abroad in Civil or Commercial Matters, concluded on March 18, 1970, after Canada joined the Conference, has also been submitted to the provinces for comments before Canada decides whether or not to accede to it. It contains reservations with respect to language requirements, delays and pre-trial discovery.

Of the post-1968 conventions with a federal State clause, the most successful one is the Convention on the Civil Aspects of International Child Abduction

3. Constitution Act (1867), 30 \& 31 Vict., c. 3, as amended, especially ss. 91-92.

4. The Convention came into force for Canada on May 1, 1989. 
concluded on October 25,1980 , which allows for a reservation on legal aid. It came into force throughout Canada on 1 April 1988, having been implemented at all levels of government with or without the reservation.

The 1985 Convention on the Law Applicable to Trusts and their Recognition contains a declaration to include trusts created judicially and reservations to allow mandatory rules, to exclude trusts governed by the law of a non-contracting State, and to exclude retroactive effect. It was signed by Canada on October 11, 1988, and has been implemented by a number of provinces with the declaration and with or without the reservation on retroactive effect. Consultations with the provinces are now taking place with respect to the implementation of the 1988 Convention on the Law Applicable to Succession to the Estates of Deceased Persons before accession by Canada.

It should be mentioned that in the field of torts, the Yukon ${ }^{5}$ has adopted the uniform Conflict of Laws (Traffic Accidents) Act $^{6}$ which is based on the Hague Convention on the Law Applicable to Traffic Accidents concluded on May 4, 1971.

\subsection{International Civil Aviation Organization}

Although Canada has not yet acceded to the 1948 Convention on the Recognition of Rights in Aircraft, implementing legislation has been passed in two provinces. Other provinces have also indicated their support for the Convention.

\subsection{United Nations Commission on International Trade $\mathrm{Law}^{7}$}

The 1958 Convention on the Recognition and Enforcement of Foreign Arbitral Awards as well as the 1985 Model Law on International Commercial Arbitration are in force throughout Canada as they have been implemented by legislation at all levels of government. ${ }^{8}$ On April 2\$, 1991, Canada acceded to the 1988 Convention on Contracts for the International Sale of Goods, which contains a federal State clause and allows for some reservations. It has been implemented by federal and provincial legislation.

This very brief survey indicates that, in recent years, Canada has taken a greater interest in international conventions dealing with topics of a social or economic

5. S.Y.T. 1972 (1st sess.), c. 3.

6. 1970 Proceedings of the Uniform Law Conference p. 263.

7. Excluded from the scope of this paper because it does not deal with private international law, is the 1973 Convention prepared by the International Institute for the Unification of Private Law providing a Uniform Law on the Form of an International Will which is now in force in most of Canada.

8. See J.-G. Castel et al., The Canadian Law and Practice of International Trade (1991) ch. 18, at p. 483. 
nature. In fact, it was one of the first States to implement the Model Law on International Commercial Arbitration. At present, Canada is very interested in the elaboration of a Hague Convention on inter-country adoption ${ }^{9}$ and a Unidroit Convention on security interests in mobile equipment, as the choice of law rules in force in Western Europe and North America are inadequate to meet the needs of those who engage in modern financing transactions involving collateral in the form of mobile equipment such as trucks and construction equipment.

\section{3.}

\section{THE PRINCIPLE OF PROXIMITY}

In recent years, in cases involving one of more legally relevant foreign elements, Canadian courts have become very interested in applying the principle of proximity as a general rule or as an exception to determine the applicable law or the jurisdiction of domestic and foreign courts.

In theory, the principle of proximity means that the courts will apply to a particular legal relationship the local law of the State or province with which it has the most real and substantial connection, that an action must be brought before the court of the State or province with which it has the most real and substantial connection and, that a foreign judgment will be recognized and enforced only if the original court had a most real and substantial connection with the action. The principle of proximity seeks to achieve more effectively some of the basic objectives of private international law, particularly justice of the end result. ${ }^{10}$

\subsection{Contracts}

Historically, it is in the field of contracts that the principle of proximity was first adopted as a general rule. Thus, it is now well established in Canada that where the parties have not expressly selected the law applicable to their contract and no such selection can be inferred, the proper law is the system of law with which the contractual transaction has the most real and substantial connection. ${ }^{11}$ This principle has also been applied to marriage contracts or settlements ${ }^{12}$ and to the

9. A Canadian was elected chairperson of the special commission in charge of drafting this convention.

10. In general see H. Yntema, 'The Objectives of Private International Law', 35 Can. Bar Rev. (1957) p. 721. Also the Restatement of the Law Second, Conflict of Laws 2d (1971) s. 6.

11. See, for example, Imperial Life Assurance Co. of Canada v. Colmenares [1967] S.C.R. 443; the whole category of contract and not just one particular legal issue is governed by the law most substantially connected, although depeçage is always possible. J.-G. Castel, Canadian Conflict of Laws, 2nd edn. (1986) s. 406, at p. 535.

12. See Devos v. Devos [1970] 2 O.R. 323 (CA) and s. 58 of the Family Law Act 1986, S.O. 1986, c. 4. 
validity of trusts inter vivos of interests in movables ${ }^{13}$ It means that there will be no automatic change in the law applicable to the marriage contract or settlement once the spouses have moved their matrimonial home to another country even if that country now has a more real and substantial connection with their financial interests, because the real and substantial connection must exist at the time when the marriage contract or settlement was entered into by the spouses.

As a general rule, the principle of proximity may be potentially dangerous since, in the absence of settled connecting factors, it cannot always achieve certainty and predictability which are important objectives in the field of contracts. However, it has the advantage of eliminating the need for characterization in borderline cases where the choice is between contracts and torts. It is also more likely to achieve justice in the individual case. Finally, it excludes the theory of renvoi. ${ }^{14}$ Fortunately, Canadian courts have clearly indicated which connecting factors they will consider as most relevant when determining the law that has the most real or substantial connection with a particular type of transaction or issue. When two or more of these factors point to a particular place, it is almost impossible to apply the law of another place. Thus, it is still possible to achieve predictability and to protect the justified expectations of the contracting parties. Actually, all they have to do to avoid any uncertainly is to select expressly the applicable law. It should be pointed out that Canadian courts do not first choose the 'better law' and then justify their choice by selecting the connecting factors that lead to its application.

\section{$3.2 \quad$ Torts}

It is in the field of torts that Canadian courts appear to be moving toward the adoption of the principle of proximity as an exception. If the application of the general choice of law rule results in the designation of a law that has no or little significant connection with the occurrence and the parties, the courts, in order to achieve justice in the particular case, will apply the principle of proximity as an exception to the general rule. Here, the principle of proximity performs a corrective function. A good example would be to apply the law of the residence of the victim instead of the law of the place of the accident where such place is purely fortuitous.

In Canada, the general common law private international law rule applicable to foreign torts was adopted in England more than a century ago: ${ }^{15}$

'As a general rule, in order to found a suit in England for a wrong alleged to have been committed abroad, two conditions must be fulfilled. First, the wrong must be of such a

13. J.-G. Castel, Canadian Conflict of Laws, 2nd edn. (1986) s. 362, at p. 481 . See also Art. 7 of the 1988 Hague Convention on the Law Applicable to Trusts that has been implemented in several provinces.

14. J.-G. Castel, Canadian Conflict of Laws, 2nd edn. (1986) s. 413, at p. 545.

15. Phillips v. Eyre (1870) L.R. 6 Q.B. 1, at pp. 28-29. 
character that it would have been actionable if committed in England .. . Secondly, the act must not have been justifiable by the law of the place where it was done.'

In the common law world, much difference of opinion has arisen with respect to the interpretation and application of this general rule. There is a substantial body of judicial opinion which holds that both conditions determine the jurisdiction of the courts over the cause of action, i.e., foreign torts. Once they have been met, the lex for $i$ applies to questions of substance and procedure. The primacy given to the lex fori would encourage forum shopping although it could be controlled by the doctrine of forum non conveniens. Questions of substance should not be determined by the lex for in its domestic sense, especially when that law has no connection with the forum. To interpret the general rule as jurisdictional in nature would often lead to unjust results. This is why, in Canada, the courts consider it to be a true double-barrelled choice of law rule. ${ }^{16}$

The first condition of the rule that a wrong must be of such a character that it would have been actionable if committed in England has not given rise to much controversy. The claim must have arisen in circumstances that if they had occurred in the forum, a cause of action would have arisen entitling the plaintiff to enforce against the defendant a civil liability of the kind which the plaintiff claims to enforce. In other words, civil liability must exist under the lex fori.

It is with respect to the meaning of the second condition of the rule, i.e., the act must not have been justifiable by the law of the place where it was done, that much confusion still exists today due to many divergent interpretations. The issue is whether something other than civil liability is sufficient to render an act not justifiable.

In Canada, the Supreme Court in McLean v. Pettigrew, ${ }^{17}$ adopted the interpretation given to that condition by the English Court of Appeal in Machado v. Fontes ${ }^{18}$ that not justifiable means not legally innocent. Thus, criminal liability is sufficient to render an act not justifiable even though it does not give rise to any civil actionability or liability. Machado v. Fontes has been much criticized and was overruled by a majority of the House of Lords in Chaplin v. Boys ${ }^{19}$ which held that the act is not justifiable only if it is civilly actionable under the lex loci delicti. The concept of civil actionability is also subject to several interpretations. It could mean (a) actionability by the lex loci delicti whether or not damages can be

16. J.-G. Castel, Canadian Conflict of Laws, 2nd edn. (1986) s. 469 at p. 605, and generally see P. Bates, 'Foreign Torts: The Canadian Choice of Law Rule', 8 Adyocate Q. (1987) p. 397.

17. [1945] S.C.R. 62.

18. [1897]2 Q.B.231 (CA). Some members of the court considered that the act complained of must not be 'innocent' in the country where it was done and that if the act was contrary in any respect to the law of that country, though giving rise to no civil liability there, it was not 'justifiable' for the purpose of the second condition.

19. [1971] A.C. 356. 
recovered, for instance where the act creates a cause of action but there exists a complete defence which precludes civil liability from arising, or (b) some civil liability under the lex loci delicti even though some of the damages claimed by the plaintiff cannot be recovered under that law, ${ }^{20}$ or (c) civil liability in accordance with the lex loci delicti including the extent of such liability. Here, the provisions of the lex loci delicti denying, limiting or qualifying the recovery of damages must be taken into consideration before determining whether the act is not justifiable by that law. The question is not whether the act was innocent but whether civil liability existed in respect of the relevant claim as between the actual parties under the lex loci delicti of the kind sought to be imposed under that law. ${ }^{21}$.This interpretation is consistent with the vested rights theory adopted in Phillips v. Eyre. ${ }^{22}$ It also achieves the objective of certainty and, in the case of interprovincial torts, gives recognition to the laws in force at the place of tort. An individual should not be able to claim in the forum in respect of a matter for which civil liability does not exist or is excluded under the law of the place where the wrong was committed.

In Chaplin v. Boys, the House of Lords did not replace the rule in Phillips v. Eyre by the principle of proximity. ${ }^{23}$ However, Lords Hodson and Wilberforce introduced this principle as an exception in the name of flexibility in order to achieve individual justice in cases where with respect to a particular issue, the place of the tort has little interest in seeing its law applied due to a lack of other proper connections. ${ }^{24}$ This exception finds its justification in the language used by Willes J. in Phillips v. Eyre when he said '[a]s a general rule'. ${ }^{25}$ The exception to the general rule should discourage forum shopping. It does not confer an unfettered judicial discretion away from the lex loci delicti or the lex fori, enabling the general rule to be ignored in arbitrary fashion, as there must be a sufficient justification to apply it.

In Canada, the courts are still trying to find ways to escape the clutches of Machado v. Fontes. Thus, in Grimes v. Cloutier and Cloutier, ${ }^{26}$ the respondent, a resident of Ontario, while riding as a passenger in an automobile registered and insured in Ontario and driven by an Ontario resident, sustained personal injuries as a result of a collision in Quebec with an automobile registered and insured in

20. This was the situation in Chaplin v. Boys, supra n. 19.

21. Lord Wilberforce in Chaplin v. Chaplin, supra n. 19, at p. 389. It is the relevant claim as between the actual parties which must be looked at, and not whether such a claim would in theory be actionable. Per Dunn L.J. in Armagas Ltd. v. Mundogas S.A. [1986] 1 A.C. 717, at p. 753 (CA); also Goff L.J. at p. 740; and Breavington v. Godleman (1988) 62 A.L.J.R. 447 (Australia HC).

22. (1870) L.R. 6 Q.B. 1, at p. 28.

23. Also called the proper law of tort. See Restatement of the Law Second, Conflict of Laws $2 d$ (1971) ss. 145-146.

24. [1971] A.C. 356 , at pp. $377-378,380,391-392$.

25. (1870) L.R. 6 Q.B. 1.

26. (1989) 69 O.R. (2d) 641 (CA). 
that province driven by the first appellant and owned by the second appellant, both residents of Quebec. The first appellant had been found guilty of driving in breach of the Quebec Highway Code $^{27}$ at the time of the collision. The respondent had received benefits in full satisfaction of all amounts payable to her in accordance with the provisions of the Quebec Automobile Insurance Act, ${ }^{28}$ which as a result of an agreement between Quebec and Ontario were part of the Ontario standard automobile policy. In addition, she brought an action for full common law damages in Ontario against the two Quebec residents in order to obtain more than that which was provided by the Quebec insurance scheme which barred a civil action. The trial judge found for the respondent as he refused to distinguish the facts of this case from those of McLean v Pettigrew. ${ }^{29}$ On appeal, the Ontario Court of Appeal preferred to distinguish McLean v. Pettigrew on the facts, than to re-interpret the second rule in Phillips v. Eyre on the ground that:

'Whatever weakness there may be in the interpretative reasoning in Machado v. Fontes, a countervailing consideration should also be noted: as a matter of policy an inflexible rule that the absence of civil liability in the place where the alleged tort took place is a valid defence can, in some cases lead to an unjust result. ${ }^{30}$

In the arduous task of distinguishing McLean v. Pettigrew from the facts of the case under appeal, the court resorted to a variety of arguments, some of which are of dubious value. First, a review of a number of Canadian decisions which applied McLean v. Pettigrew enabled the Court of Appeal to conclude that this case did not preclude the application of the law of Quebec. Although the court admitted that in the past the residence of the parties may not have been a decisive factor in interpreting the second rule in Phillips v. Eyre, it attached great importance to the fact that in the case under review the two appellants were resident in the place where the accident occured whereas this was not so in McLean v. Pettigrew. Yet, it should be noted that in the latter case, the residence of all the parties in the place where the action was brought may have been the decisive factor in allowing recovery by the gratuitous passenger. The Court of Appeal also relied upon the qualifying clause '[a]s a general rule' used by Willes J. in Phillips v. Eyre in his

27. R.L.Q. 1977 , c. C-24, s. 83.

28. L.Q. 1977 , c. 68 , especially ss. 4 and 8.

29. In McLean v. Pettigrew [1945] S.C.R. 62, the accident occurred in Ontario. The plaintiff was a gratuitous passenger in the automobile driven and owned by the defendant. Both parties resided in Quebec and the automobile was registered and insured in that province. If the accident had taken place in Quebec, the defendant would have been civilly liable for the plaintiff's damages whereas in Ontario at that time it was difficult to hold drivers and owners civilly liable to gratuitous passengers. As the Supreme Court found the defendant to have driven in a careless manner in breach of the Ontario Highway Traffic Act, the wrong was not justifiable under the lex loci delicti and the gratuitous passenger was able to recover her damages.

30. (1989) 69 O.R. (2d) 641 (CA), at p. 649. 
statement of the rule to point out that it admits exceptions. Since in McLean v. Pettigrew, the court also used the prefatory words '[u]nder these conditions, ${ }^{31}$ there were good reasons for the Court of Appeal in the light of these other factors not to apply the second rule in Phillips v. Eyre in all cases involving foreign torts, especially if it would lead to an unjust result as in the case under appeal. In McLean v. Pettigrew, the result on the facts was a just one which could also have been reached by applying the principle of proximity. In the present case, the accident took place in Quebec where it was covered by the Quebec automobile compensation scheme. The appellants, as residents of that province, were legally entitled to the protection of that scheme. It would have been unjust to submit them to the law of Ontario and destroy their reasonable expectations of the legal consequences of their conduct. As for the respondent victim, the court stated that it would be difficult to believe that she would have had any reasonable expectation that Ontario law would apply to the exclusion of Quebec law with respect to any driving accident occurring in Quebec. This view, however, emphasizes the place of the accident rather than the residence of the tortfeasor. Finally, the Court of Appeal added that comity as between the provinces required one province when applying its laws not to ignore the policies of another province as expressed in its legislation. Thus, the court concluded that, on the facts of the case, it should not apply the 'punishable' gloss of the second rule in Phillips v. Eyre. Since the appellants were not civilly liable to the respondent for the accident in Quebec, her claim failed.

Today, at least in Ontario, until the Supreme Court of Canada reconsiders the general rule, where the defendant resides in the place of the tort, not 'justifiable', in Phillips v. Eyre, means the existence of civil liability only, in respect of the relevant claim as between the actual parties, of the kind sought to be imposed under that law. However, Machado v. Fontes continues to apply to some situations in order to achieve individual justice.

The decision of the Court of Appeal is a disguised attempt to adopt the principle of proximity as an exception since the application of the test in McLean $\mathrm{v}$. Pettigrew or the one in Grimes v. Cloutier and Cloutier depends upon the existence of certain connecting factors that indicate which jurisdiction has the most real and substantial connection with the occurrence and the parties with respect to a particular issue. ${ }^{32}$ Probably, the court took this approach because it favoured reforming the law by legislative rather than by judicial intervention. ${ }^{33}$

31. [1945] S.C.R. 62, at p. 76.

32. See also Gagnon v. Gagnon (1991) 3 O.R. (3d) 38.

33. Many other Canadian courts have expressed the view that, were it not for the decision of the Supreme Court of Canada in McLean v. Pettigrew, they would have adopted the principle of proximity either as a general principle or as an exception. Note that in England, Dicey and Morris, The Conflict of Laws, 11th edn. (1987), adopt the principle of proximity as an exception: rule 205(2) at pp. 13651366, whereas the American Law Institute's Restatement of the Law, Second, Conflict of Laws $2 d$ 
In the field of foreign torts, the principle of proximity should be invoked only in special circumstances where, after an examination of the policy underlying the laws which may be applied under Phillips v. Eyre and the interests of the parties to be affected, it is clear that the lex loci delicti has no real and substantial connection with the proceedings.

The use of the principle of proximity as an exception in order to correct an anomalous situation is justifiable where certainty, predictability and uniformity of results are not important considerations.

\subsection{Jurisdiction of courts}

The principle of proximity which has been applied by Canadian courts as a general rule or as an exception in choice of law cases has not played a comparable role in the area of conflicts of jurisdictions. This is surprising as it would seem logical and just for the court applying the law most really and substantially connected to be also the one that is most really and substantially connected with the lawsuit. However, indirectly, the principle of proximity has worked its way into conflicts of jurisdictions through the doctrine of forum non conveniens.

In Canada, at common law, the primary rule to determine whether a court has jurisdiction in personam to hear and determine an issue upon which its decision is sought, is that so long as the defendant is personally served with a writ or originating process in the court's territory, that court can hear the matter. The presence of the defendant is paramount. However, since in disputes involving one or more legally relevant foreign elements, it is possible for a defendant to avoid service of the writ or originating process by leaving the province or Canada, or by remaining abroad, provincial and federal rules of procedure list the specific circumstances where a person may be served outside the court's territory, for instance if relief is sought against a defendant domiciled or ordinarily resident or carrying on business in the jurisdiction. ${ }^{34}$ The rules governing service outside the court's territory determine when the court has jurisdiction over a defendant outside the province or Canada. Once served, within or without the province or Canada, the defendant may move for an order to set aside the service or to stay the proceeding, on the ground that the court is forum non conveniens for the hearing of the proceeding. It is at this stage of the proceeding that the principle of proximity comes into the picture in order to set aside the relevant jurisdictional rule when warranted by the circumstances. Thus, in Canada the most real and substantial connection is not a general principle for the exercise of jurisdiction.

(1971) adopts it as a general principle: s. 145, at p. 414.

34. For an analysis of these rules see J.-G. Castel, Canadian Conflict of Laws, 2nd edn. (1986) ch. 11 , at p. 187. 
The doctrine of forum non conveniens was developed in order to prevent Canadian courts from accepting jurisdiction, when it was more appropriate for a court in another province or country to hear the lawsuit because the connection with the court selected by the plaintiff was negligible or non existent.

In the area of jurisdiction, convenience, fairness and justice are the objectives that must be taken into consideration when applying the principle of proximity which finds its expression in the doctrine of forum non conveniens. The court that has the most real and substantial connection with the lawsuit is the forum conveniens since it will be able to achieve justice at much less inconvenience or expense to the parties than the court having jurisdiction by application of the established ground or factor upon which such jurisdiction is based. In other words, the principle of proximity is tied to the issue of suitability or appropriateness of the forum.

The doctrine of forum non conveniens seeks out the natural forum which is the one with which the lawsuit has the most real and substantial connection. The court must look for connecting factors in this sense. These factors include not only factors affecting convenience or expense but also other factors such as the law governing the relevant transaction and the places where the parties, respectively, reside or carry on business. When they have exercised their discretion to decline jurisdiction on the basis of the doctrine of forum non conveniens, Canadian courts have relied upon cases such as Rockware Glass Ltd. v. MacShannon ${ }^{35}$ and Spiliada Maritime Corp. v. Cansulex Ltd. ${ }^{36}$ two decisions of the House of Lords.

In Bonaventure Systems Inc. v. Royal Bank of Canada, the Ontario Divisional Court stated: ${ }^{37}$

'As part of the first stage, the applicant for a stay must satisfy the court that the foreign jurisdiction is the convenient forum. Convenient forum means that the applicant must establish that the foreign jurisdiction is the more appropriate natural forum to try the action in the sense that the foreign jurisdiction has the most real and substantial connection with the lawsuit. It will be presumed that justice can best be obtained in the foreign jurisdiction if it is the natural forum in the sense that justice can be done between the parties at substantially less inconvenience or expense in the natural forum of a lawsuit. However, in the exceptional case, justice may not be best done in the natural forum where a substantial number of major witnesses reside in the other jurisdiction.

35. [1978] A.C. 795 (HL).

36. [1987] A.C. 460 (HL).

37. (1986) 32 D.L.R. (4th) 721 (Ont. DC), at pp. 729-730; Patseas v. Castelo (1988) 54 D.L.R. (4th) 573 (BCCA); Antares Shipping Corp. v. The Ship 'Capricorn' [1977] 2 S.C.R. 422; United Oilseed Products Ltd v. Royal Bank [1988] 5 W.W.R. 181 (Alta. CA). For a survey see J.-G. Castel, Canadian Conflict of Laws, 2nd edn. (1986) Ch. 13, at p. 219, Supplement (1990), at p. 18 et seq. Also J.W. Horn, Court Jurisdiction (1989) Ch. XXI, at p. 108. 
The applicant for a stay of an Ontario action must thus establish that justice can clearly be best done in the foreign jurisdiction. That test satisfied, the applicant is still not yet entitled to a stay.

The second stage of an application for a stay of an Ontario action in a case of competing jurisdiction raises the question as to whether the stay will deprive the respondent plaintiff of a legitimate personal or juridical advantage by maintaining the Ontario action which will not be available to him in the foreign jurisdiction. At this stage, the onus lies on the respondent plaintiff to establish the loss of a legitimate personal or juridical advantage. The court must not presume such loss.'

Since the doctrine of forum non conveniens is now applied whether the defendant is served within or without the province or Canada, it is possible to argue that the principle of proximity has become the general rule rather than a corrective for determining the jurisdiction of Canadian courts in cases involving one or more legally relevant foreign elements. In all cases, the appropriate forum must be the one which has the most real and substantial connection with the lawsuit. The traditional grounds upon which Canadian courts base their jurisdiction which are generally defined by law, are subservient to this pririciple. However, if the particular ground invoked by the plaintiff provides the most real and substantial connection, the court will not declare itself forum non conveniens.

It would seem that the doctrine of forum non conveniens which implements the principle of proximity is too rigid if it means the most real and substantial connection. In the field of conflicts of jurisdictions, unlike that of choice of law, it does not matter if several courts have jurisdiction provided the ground or factor that is used by the court constitutes $a$ sufficient connection.

\subsection{Recognition and enforcement of foreign judgments}

Following English precedent developed in the 19th century, it had long been established in common law Canada that a foreign court has 'international' jurisdiction to pronounce a judgment in personam capable of recognition and enforcement where, at the date of commencement of the proceedings, the defendant was resident or present within the country, state or province of that court or, if a corporation, was carrying on business there. In addition, 'international' jurisdiction was recognized where the defendant, in the character of the plaintiff had selected the court in which he or she was afterwards sued or where he or she had submitted or agreed to submit to the jurisdiction of that court. Other bases for the exercise of jurisdiction by a foreign court were not recognized. ${ }^{38}$

38. For a survey see J.-G. Castel, Canadian Conflict of Laws, 2nd edn, (1986) at pp. 240-247; see, e.g., Emanuel et al. v. Symon [1908] 1 K.B. 302 (CA); Forbes v. Simmons (1914) 20 D.L.R. 100 (Alta. SC); Marshall v. Houghton [1923] 2 W.W.R. 553 (Man. CA); Standal's Patents Ltd. v. Lakeland Mills Ltd. (1990) 31 C.P.R. (3d) 167 (BCSC Master). 
As already indicated, in all the common law provinces, the rules of civil procedure allow for service out of the province on certain grounds which go far beyond those that are traditionally recognized as giving international jurisdiction to a foreign court. However, a judgment rendered in a province on any of these grounds cannot be enforced in another province if it is not one that gives the original court international jurisdiction in the eyes of the enforcing court. Thus, until recently, in cases where jurisdiction was based on grounds not recognized by the courts of the State or province where the debtor resided or had assets, the best tactic was not to appear at all before the foreign court and then resist the enforcement of the foreign default judgment by arguing that the original court lacked international jurisdiction. To overcome this situation, some courts resorted to jurisdictional reciprocity or bilaterality. ${ }^{39}$ It was not until 1991 that Canadian courts moved away from traditional jurisdictional rules with respect to the recognition and enforcement of the judgments of sister provinces. The seminal decision that accomplished this revolution was given by the Supreme Court of Canada in De Savoye v. Morguard and Investments Ltd. ${ }^{40}$

The facts of this case are simple. The respondents, Morguard Investments Ltd. and Credit Foncier Trust Company, became mortgagors of lands in Alberta in 1978. The appellant, De Savoye, who then resided in Alberta and originally the guarantor, took title to the lands and assumed the obligations of mortgagor. Subsequently, he moved to British Columbia where he established his residence after severing all his business and other ties with Alberta. When the mortgages fell into arrears, the respondents brought actions in Alberta for foreclosure and served the appellant in British Columbia pursuant to Rule $30(\mathrm{~g})$ of the Alberta Rules of Court. ${ }^{41}$

The appellant did not appear or defend the actions, nor was he under any contractual obligation to submit to the jurisdiction of the Alberta Court. The respondents obtained judgments nisi in the foreclosure actions. At the expiry of the redemption period, they became the owners of the mortgaged properties as a result of a judicial sale and judgments were entered against the appellant for the

39. Marcotte v. Mergson (1987) 19 B.C.L.R. (2d) 300, 24 C.P.C. (2d) 201 (Co. Ct. BC). The enforcing court should recognize and enforce a judgment from another province if the original court took jurisdiction in circumstances where, if the facts were transposed to the enforcing province, its courts would have taken jurisdiction.

40. (1991) 76 D.L.R. (4th) 256, 122 N.R. 81, [1990] 3 S.C.R. 1077.

41. The rule provides that:

'Service outside of Alberta of any document by which any proceeding is commenced, or of notice thereof, may be allowed by the Court whenever: ...

(g) the action is in respect of a breach committed within or out of Alberta, and irrespective of the fact, if that is the case, that the breach was preceded or accompanied by a breach committed out of Alberta that rendered impossible the performance of so much of the contract as ought to have been performed within Alberta;'

This rule is substantially similar to British Columbia Rule $13(1)(\mathrm{g})$. 
deficiencies between the amount obtained for the properties and the amount owing on the mortgages. Action was then taken by each of the respondents to enforce the Alberta judgments for the deficiencies. Judgment was given in their favour by the Supreme Court of British Columbia, a decision which was upheld by the Court of Appeal. On a further appeal, the Supreme Court of Canada, when confirming this decision, rejected the test of jurisdictional reciprocity which had been applied by the courts below in favour of a modified principle of proximity.

The court was of the opinion that the proper test to be applied is whether it is inherently reasonable for the action to be brought in a particular jurisdiction. In other words, where the defendant or the subject matter of the dispute had $a$ (and not the most) real and substantial connection with the court that gave the judgment, it is reasonable that such judgment be recognized in other provinces. This is called 'interprovincial comity' in the sense of mutual self-interest and convenience. In the present case, it was reasonable for the Alberta court to have taken jurisdiction because the properties were situated in that province and the contracts had been entered into there by parties then both resident in Alberta. Generally speaking, the principle of proximity in this milder form is more logical and practical than jurisdictional reciprocity for determining the 'international' jurisdiction of the original court. It is much wider, less rigid, does not create difficult problems of interpretation and constitutes a true rule of private international law in the field of conflicts of jurisdictions. The new test is designed to enlarge the grounds upon which Canadian courts recognize the jurisdiction of the courts of other provinces for the purpose of enforcing their judgments at common law. It is an all-embracing test since it includes the traditional common law grounds of 'international' jurisdiction. There is no danger that the sovereignty of the province of the enforcing court will be jeopardized by the exercise of jurisdiction by the original court, since the enforcing court is the sole judge as to what constitutes $a$ real and substantial connection. Therefore, this test could also be applied to judgments rendered in foreign States. ${ }^{42}$ In some cases, the application of the test could result in a situation where the original court had 'international' jurisdiction in the eyes of the enforcing court even though that court would not possess jurisdiction in similar circumstances. This is one of the differences that exist between reciprocity and proximity. What constitutes $a$ real and substantial connection is not always easy to determine. For instance, should personal property within the jurisdiction constitute $a$ sufficient real and substantial connection? Should it make any difference whether the property is in Canada or abroad? Eventually, the courts of each province will

42. This was done in Clarke v. Lo Bianco (1991) 59 B.C.L.R.(2d) 334 (BCSC) where the court went as far as to accept the existence of a real and substantial connection with California at the time the cause of action arose which was no longer present at the time when the action was begun in the California court. Also Minkler \& Kirshbaum v. Sheppard (1991), 60 B.C.L.R. (2d) 360 (SC); Federal Deposit Insurance Corp. v. Vanstone (1992), 63 B.C.L.R. 190, 88 D.L.R. (4th) 448 (SC); Moses v. Shore Boat Builders (1992), 68 B.C.L.R. (2d) 394 (SC). 
develop their own rules as to what amounts to $a$ real and substantial connection in a particular situation in order to recognize the 'international' jurisdiction of the original court at common law. Probably, some of the grounds for service ex juris used by the enforcing court could be recognized as constituting $a$ real and substantial connection for the original court.

With respect to the issue of forum non conveniens, and the discretionary power of the court, it is difficult to see how the enforcing court could refuse to recognize the jurisdiction of the original court on the ground of forum non conveniens when it is based on $a$ real and substantial connection, since it is generally admitted that the natural forum for the trial of an action is that with which the action has the most real and substantial connection. The statement by the Supreme Court of Canada that permitting suit where there is $a$ substantial connection with the action provides a reasonable balance between the rights of the parties, opens the door to the full recognition of the principle of proximity as the general rule for the exercise of jurisdiction by Canadian courts. ${ }^{43}$ Whether this new approach should be supported is doubtful. In our opinion, the principle of proximity should only be resorted to as an exception when it is necessary to correct a bad situation.

\section{THE NEW CIVIL CODE OF QUEBEC}

On December 18, 1991, the Quebec National Assembly adopted the Civil Code of Quebec which will come into force in $1994^{44}$ and replace the Civil Code of Lower Canada enacted in 1865. Book ten of the new Code is devoted to private international law. Other parts of the Code deal with domicile and residence and the proof of foreign law and foreign documents. It is not within the scope of this paper to analyze the new rules of private international law. What should be mentioned, however, is that these rules have a chequered origin. They are based in part on a project prepared by the Private International Law Committee of the Office of Revision of the Civil Code which incorporated the provisions of some of the Hague Conventions ${ }^{45}$ and, in part, on the 1987 federal law of Switzerland devoted to private international law, as well as the 1980 EEC Convention on contractual obligations. It is also interesting to note that the principle of proximity is adopted by the Code which provides that, exceptionally, the law normally applicable will be set aside, if in the light of all attendant circumstances, it is clear that the situation is only remotely connected with that law and is much more closely

43. (1991) 76 D.L.R. (4th) 256, at p. 277.

44. L.Q. 1991 , c. 64.

45. Office of Revision of the Civil Code, Report on the Quebec Civil Code (1977), Vol. I, at p. 593 et seq. 
connected with the law of another State. This provision which acts as a corrective, does not apply where the law is designated in a legal instrument. ${ }^{46}$

The principle of proximity is also used directly to determine the law applicable to obligations ${ }^{47}$ and the international jurisdiction of Quebec judicial and administrative authorities ${ }^{48}$ and, indirectly, to test the jurisdiction of foreign judicial and administrative authorities ${ }^{49}$ for the purpose of recognizing and enforcing a foreign decision. ${ }^{50}$

\section{CONCLUSION}

The recent evolution of some Canadian private international law rules indicates that the close association that has existed between Canada and the Hague Conference for the past twenty-four years has been mutually beneficial. By participating actively in the work of all its sessions, and implementing a certain number of its conventions, Canada has been able to align some of its private international law rules on those of the rest of the world. The country has finally begun to emerge from its splendid international legal isolation! On the other hand, Canada's long experience with interprovincial conflicts, its successful attempts at unification of the law on the domestic level through the Uniform Law Conference have enabled it to make a substantial and original contribution to the work of the Hague Conference. In the future, this successful cross-pollination can only accelerate the process of world-wide unification of private international law rules to the advantage of all.

46. Art. 3082. This is based on Art. 15 of the Swiss law.

47. Arts. 3112-3113.

48. Arts 3135-3136.

49. Art. 3164 .

50. Art. 3155(1). In general see E. Groffier, 'La réforme du dorit international privé', 52 R. du B. (1992) p. 627; J.G. Castel, 'Commentaire sur certaines dispositions du Code civil du Québec se rapportant au droit international prive', 119 Clunet (1992) p. 625. 